\title{
The Comic in the Republic of Machado de Assis
}

\author{
Antônio Joaquim Pereira Neto ${ }^{1}$ \\ ${ }^{1}$ IFBA-Federal Institute of Education, Science and Technology of Bahia. Paulo Afonso/BA, Brazil \\ Correspondence: Rua Marcondes Ferraz, 200. Bairro General Dutra, Paulo Afonso/BA, Brazil. Tel: (75)-9928- \\ 25545. E-mail: $\quad$ antoniojoaquimpereiraneto@gmail.com
}

Received: April 8, 2019; Accepted: April 22, 2019; Published: May 4, 2019

Nucleus of Research in Humanities, Education and Science (NUPHEC).

\begin{abstract}
This article analyzes the tale "A Sereníssima República" (The Most Serene Republic), by Machado de Assis, approaching the rhetorical artifices of this narrative as constitutive of the conventions of the comic genre. Understanding that this genre consists in a textual unit formalized by images that subvert the common places of realistic enunciation, it points out to the presence of wonder, the fantastic in this fiction, whose conventions amplify the comic and grotesque character of the enunciation. Formed by oxymorons, paradoxical sentences and ingenious metaphors, this narrative satirizes, taking the metonymy as an interpretative procedure, the current values of politics, moral and justice present in the scenes of the nineteenth-century Brazilian republic.
\end{abstract}

Keywords: Machado de Assis, Comic, Fantastic, Republic, Rhetoric

\section{Introduction}

A critical study of the tales by the Brazilian writer Machado de Assis can be carried out against the conventions of the aesthetics of realism. Therefore, this analysis demands the knowledge of the discursive properties formalized in these narratives. "These properties arise either from the semantic aspect of the texts, or from its syntactic aspect, or verbal aspect etc" (Todorov and Richard, 1976, p. 163). In other words, the identification of the determinations of meaning of the narrative in question presupposes a perception of the genre responsible for the configuration of the elements of form and content that constitute the characteristics of this object, once "a genre, literary or otherwise, is nothing but this codification of discursive properties" (Todorov and Richard, 1976, p. 162). In the case of Machado's narratives, it is noted that the comic is the genre that links coherence in the plot of his stories, mediated by ingenious metaphors, whose paradoxical images destabilize the seriousness of the philosophical semantics of their moral contents. Through an allegorical reading, these images figure a satire to the social and political basis of the Brazilian nineteenth century universe.

\section{Conventions of the Comic Genre}

Starting from these initial considerations, the genre appears, in this approach, as a textual unit endowed with linguistic properties that allow its classification according to the rhetoric of its effects. Thereby, this article understands that "the accounts of the existence of genre" for an analysis of the tales of this writer, "must have the establishment of these properties as its final objective" (Todorov and Richard, 1976, p. 162). Therefore, the objective of this text is to evidence the conventions of the comic genre and the fantastic genre as constitutive of syntactic and rhetorical properties that point to semantic incongruities that can be identified by the audience of these narratives. It comes from the hypothesis that these semantic incongruities allegorize, in the tale The Most Serene Republic, a republic dominated by the vice of corruption. Thus, understanding that comic and fantastic are linked in achieving the corresponding purposes, whereas both can be codified by an elocution of unexpected and wonderful images, it is relevant to analyze as the fantastic genre is commonly recognized, in order to understand it as the efficient cause of laughter.

For Tzvetan Todorov and Richard (1976, p. 167), this genre is characterized by the hesitation that the reader is invited to experience with regard to the natural or supernatural explanation of the events depicted". As can be noticed, the keys of the recognition of wonderful stories are pragmatic, and it is not the verbal and syntactic aspects that give them condition, since "this is a pragmatic property of the discursive situation" (Todorov, 1976, p. 167). The reader is led to doubt by a description that denotes incompatibility between the known and the narrated world. "To be more precise, the world described is certainly ours, with its natural laws, but at the heart of this universe 
an event occurs for which it is difficult to find a natural explanation" (Todorov and Richard, 1976, p. 167). Devoid of a rational explanation, by its extraordinary nature, the fantastic narrative distances itself from the realistic description, drafting for the reader the impossible (Note 1), whose lack of empirical evidence clashed with the opinions based on the aesthetic discourse of the tradition, since the "fantastic literature emerges as a site for critical debate in the eighteenty century, partly as a result of an increasing disbelief in but continued fascination with the supernatural, partly as a negative by-product of arguments for the realistic novel" (Sandner, 2004, p. 6). Likewise that Tzvetan Todorov and Richard, David Sandner emphasizes a centrality of pragmatic aspects in this genre when it harmonizes the fantastic literature with the "fascination with the supernatural."

So to speak, the fantastic genre, the basis of comicality in the featured narrative, is opposed to realistic verisimilitude (Note 2), which presupposes a narrative whose decorum the reader glimpses for its adequacy to social, political, and moral determinations of current opinions. The technique of mimetic discourse, affirms Roland Barthes (1987, p. 3), is "based on the existence of a certain verisimilitude deposited in the mind of men by tradition, wise men, the majority, current opinion, etc". Furthermore, different to the fantastic that promotes the violation of the expectations of the reader by its disagreement in relation to the present values, "what is convincing in a work" or mimetic discourse "is that which contradicts none of these authorities" (Barthes, 1987, p. 3). In this sense, this article notes that the tale The Most Serene Republic is based on current opinions about the values that conditioned the vision of the nineteenth century Brazilian reader to perform his satire to the political foundations of that society, through a technique that figures the comic in a syntax that harmonizes sublime words with vulgar words, converting these inferior linguistic units, condensed in oxymorons, in immediately superior linguistic units that amplify the paradox, the semantic incongruities that appear the lack of logic of the republic figured by the author of the novel "Dom Casmurro".

To surprise these current opinions, Machado de Assis produces the fantastic from the effects of syntactic properties that subvert the apodictic logic of rational discourse. That is what allows for the perception of the impossible and the semantic impertinences in the form of the narrative, which replicate the allegory as a continuous metaphor of these syntactic properties materialized in the body of the text. So, advancing in the perspective approached by Todorov, it is ratified in this text that the pragmatic properties of the discursive situation that ensure the identification of the wonder in the narrative under analysis are also effects of the oxymorons, metaphors, sentences, maxims and statements that oblige the reader to recognize the technique, the artifices of the narrative language, the ingenious rhetoric of the writer in the use of tropes (Note 3). "Therefore the need to analyze the rhetoric of this author's fiction, since he cannot choose whether to use rhetorical heightening. His only choice is of the kind of rhetoric he will use" (Booth, 1983, p. 116). Considering that one of the objectives in this text is to evidence the discursive properties that engender the meanings of Machado's tale, the present article is "interested in how specific novels", as the tale that will be described "achieve rhetorical effects by playing with the means and conventions made available to them by the genre" (Schneider, 2015, p. IX).

\section{Paradoxical Sentences and Ingenious Metaphors}

Thus, after the considerations presented, it will be evidenced that Machado de Assis, like Swift, Voltaire, Luciano de Samósata and Sterne, "will clearly sacrifice realism whenever their satirical ends require the sacrifice" (Booth, 1983, p. 57). The most serene republic' tale is a demonstration of the ends. The story is narrated by Cônego Vargas who, right in the beginning, talks about his new scientific discovery, that "will bring some luster to our nation" (Assis, 2018, p. 436):

My discovery is not a recent one; it dates from the later part of 1876. I did not reveal it then for a reason you will easily comprehend, and if it weren't for Globo, surely our capital's most interesting newspaper, I would not be revealing it now. The work I have come here to discuss with you still lacks a few final touches, verifications, and complementary experiments. Globo reported that an English expert has discovered the phonetic language of insects, citing a study undertaken with flies, I immediately wrote to colleagues in Europe, and keenly await their responses. Since it is undoubtedly the case that, in the field of aerial navigation, so ably invented by our very own Father Bartolomeu, the names of foreigners have taken all the glory, while that of our compatriot is scarcely remembered even by his own people, I was determined to avoid the fate of that eminent Flying Priest, and so have come to this rostrum to proclaim loud and clear, to the entire universe, that long before that English expert, and far beyond the British Isles, I, a humble naturalist, discovered exactly the same thing, and made a much better job of it.

The affirmation that this new discovery is the phonetic language of insects is unexpected, surprising for a reader who has never had an experience of coming across the evidence of this statement. And the narrator recognizes the extraordinary character of the story: "Gentlemen, I am about to astonish you, as I would have astonished Aristotle 
had I asked him: "Do you believe that a social order could ever be imposed upon spiders?" (Assis, 2018, p. 437). Cônego Vargas says that it is possible to accomplish the impossible, because he discovered a wonderful spider endowed with a wonderful web: "is simply impossible to believe that such a shy and solitary arthropod made for work alone and not for love, could ever be inducted into some form of social organization. Well, I have achieved the impossible" (Assis, 2018, p. 437). Against the inferiority of the spiders, this scientist defends that the spider "neither troubles nor defrauds us", that they are the best example of patience, order, foresight, respect and humanity; they have human attributes.

This rhetorical procedure was also used by Machado in "An Alexandrian Tale". In this, the character Stroibus ratifies: "the gods put the essence of all human feelings and abilities into the beasts of the earth, water, and sky. Animals are the random letters of the alphabet; man is the syntax" (Assis, 2018, p. 537). The amazement is caused by the technical procedure used, because the sentence pronounced is of a metaphorical nature, which suggests the presence of a science described by rhetorical devices. This way, considering this sentence and understanding that it would be possible to transfer the spider blood to the man and that "it would give that man the rudiments of geometry and musical sensibility" (Assis, 2018, p. 536), this proposition means that the republic of spiders described in this text constitutes a reduced model of the human social regime, which can be read metonymically by those who recognize that the figure presupposes the whole represented by the part, since the "animals are the random letters of the alphabet; man is the syntax".

Finally, seeking to safeguard the right of Brazilian science" Cônego Vargas starts his experiments with spiders in order to "give them a suitable form of government" (Assis, 2018, p. 438). Aiming to put this "young society's political skills to the test", adopts an obsolete model, inspired by the republic of Venice (Note 4), which in turn corresponds to an imitation of the model of the Platonic republic (Note 5):

I needed either to find a brand-new system, or to reintroduce one that had long since been abandoned. Naturally, I chose the latter, and nothing seemed more fitting than a republic in the Venetian mold; I even adopted the same epithet. This obsolete system, which was, in general terms, unlike any other current system of government, had the added advantage of all complicated mechanisms, namely, it would put my young society's political skills to the test. There was another motive behind my choice. Among the various electoral methods once used in the Venice of old was the bag and ball, which is how the sons of the nobility were initiated into matters of state. Balls bearing the candidates' names were placed in the bag, and every year a certain number were taken out, with the chosen few being deemed suitable for public service. Such a system will provoke laughter among experts in electoral suffrage, but that is not the case with me. For it precludes the follies of passion, the errors of ineptitude, and the commingling of corruption and greed (Assis, 2018, p. 438).

It is recognized that Plato, by the voice of Socrates, defends the knowledge of the truth of the ideal forms, responsible for the consolidation of the fair, the beauty and the good in the republic. In this work, "After introducing the idea of the Good as the greatest object of learning, Socrates explains to Glaucon that all other knowledge would be useless or at least unreliable without knowledge of the good" (Herrmann, 2007, p. 224). The rational dialectical division of forms, which discriminates the true from the false, could, in these terms, guarantee the construction of a perfect city, because the being of each form presupposes the condemnation of non-being, produced by those who used the discourse to legitimize falsehoods, like the sophists and poets, creators of simulacra, of fantastic images. In Plato's work, "idea does have a privileged status in connection with the good itself" (Herrmann, 2007, p. 225). In fact, as a creator of false forms, the fictionist keeps away from the good in itself. Hence the sense that this narrative corresponds to a copy of the copy and foments a counterfeit of the values built by the platonic philosophical system, though it is already born as a false image, like literature.

\section{Satire to the Brazilian Republic}

The republic of spiders would be unthinkable in the terms of the master of Aristotle. But as the fantastic has become the object of reflection at the time of the writing of this fiction, since it "does not become descriptive of a genre until the late nineteenth Century" (Sandner, 2004, p. 9), the understanding of the conventions of this tale enables the demonstration that Machado de Assis satirizes the foundations of the Platonic city, a utopian republic (Note 6) that evidences itself far from virtue and from its acquisition process.

With a conscience born amid the disillusionments of a peripheral nation that imitated nineteenth-century Europe's true regimes, Machado's mimesis no longer shares an "enthusiasm for moral reform gave way to the civilised and empathetic social relations of the later half of the long eighteenth century" (Schneider, 2015, p. 6). A rational and suitable republic could only be figured in the comic genre, whose images promoted the inversion of the principles which hitherto supported the philosophical, scientific, and moral ideals of the West. And here is the explanation 
of the technique that transforms the sublime into the grotesque, ingeniously described in the electoral process of that republic: "In effect, ever since they first grasped that the electoral act was the fundamental basis of public life, they set out to exercise it with the utmost punctiliousness. Weaving the bag was itself a national undertaking" (Assis, 2018, p. 439). If a national work must presuppose an excellence and effectiveness of an electoral process, corresponding to the expectations of the sages, a bag of balls, a vulgar instrument that can be manufactured by any person, it would figure the opposite in an oxymoron which points to the grotesque of a system marked by the accumulation of ruins.

At first the election passed off without incident. But soon afterward, one of the legislators declared that the election had been tainted, because the bag contained two balls each inscribed with the name of the same candidate. The assembly verified the truth of the allegation, and declared that the bag would henceforth be only two inches wide, not three, thus restricting the bag's capacity and limiting (which was as good as eliminating) the scope for fraud. However, in the following election, it transpired that the name of one of the candidates had not been inscribed on the relevant ball; whether this was due to carelessness or willful omission on the part of the public official is not known. The official insisted that he had no recollection of seeing the illustrious candidate, but nobly added that it was not impossible that he had been given the name, in which case it had not been a matter of deliberate exclusion, but of forgetfulness on his part. Faced with so ineluctable a psychological phenomenon as forgetfulness, the assembly could not bring itself to punish the official; however, in the belief that the narrowness of the bag could give rise to nefarious exclusions, it revoked the previous law and restored the bag to its full three inches (Assis, 2018, p. 440).

As can be seen, the ineffectiveness constitutes the logic of this system, dominated by parties that represent complete disorder in the political field. After successive problems with the lack of smoothness of the process, Hazeroth and Magog will become the next candidates, "the respective leaders of the rectilinear party and the curvilinear party" (Assis, 2018, p. 440). From then on, Machado will play with the persuasive effectiveness of rhetorical figures and the reader will be able to evidence this game if he remembers the metaphors of the alexandrine tale. In relation to the candidates "since arachnids are masters of geometry, it is geometry that divides them politically. Some are convinced that spiders should always spin their webs with straight threads, and they adhere to the rectilinear party" (Assis, 2018, p. 440). Indeed, the attentive reader to the moral values highlighted throughout the text by the narrator, as well as the conventions of the comic genre, to the objects of his elocution, will notice the division between the virtue idealized by the narrator and the vice outlined in the enunciation, the implicit reason in the form of honest government sought by Vargas and the irrationality of its consequences. So to speak, in Machado's game, the rectilinear party may be for reason just as the curvilinear party may be for the lack of it. In the same way that a third party can represent the two forms, which in turn would be denied, as well as the first and the second, by a fourth party.

It is worth noting the description of all the characters. Thus, "the straight line represents noble sentiments: justice, probity, integrity, and perseverance, while base or inferior sentiments such as flattery, fraud, betrayal, and perfidy are quite clearly curved" (Assis, 2018, p. 441). As the virtues are straight, rational, fair, honest, upright, and persevering, vices can only be fraudulent, disloyal, flattering, and perfidious. Nevertheless, as the paths of language bifurcate, the adversaries of the rectilinear party denounced their pretensions, affirming that "whereas ignorance, arrogance, foolishness, and boasting are straight, indeed rigidly so" (Assis, 2018, p. 441). Without the identification of a rational principle whereby it was possible to eliminate the raves of passions and the congress of moral corruption, the narrative points to the indeterminacy of the ways, since "the third party, less angular, less exclusive, has trimmed away the exaggerations of both sides and combined their contrasting positions, proclaiming the simultaneous nature of lines to be the exact representation of the physical and moral world. The fourth grouping simply repudiates everything" (Assis, 2018, p. 441).

In this moral void denounced by the plot, institutions do not work, and it doesn't matter what persevering effort is that seeks to avoid the ineffectiveness of the system, there will always be a way to empty it, to make it useless:

Neither Hazeroth nor Magog was elected. The relevant balls were drawn from the bag, but were deemed invalidHazaroth's because the first letter of his name was missing, and Magog's because his lacked the last letter. The remaining, triumphant name was that of an ambitious millionaire of obscure political opinions, who promptly ascended the ducal throne to the general amazement of the republic. However, the defeated candidates were not content to rest on the winner's laurels; they called for an official inquiry. The inquiry showed that the Inscriptions Officer had intentionally misspelled their names. The officer confessed to both the error and the intention, explaining that it had been nothing more than a simple ellipsis; a purely literary misdemeanor, if that. Since it was not possible to prosecute someone for errors of spelling or rhetoric, it seemed sensible to review the law once again (Assis, 2018, p. 441). 
The mistakes alleged in the violation of the procedures denounce a vulgarity of the behaviors, in contrast to the desire to provide "some luster to our nation". Even the figures of rhetoric serve as justification to rid the guilty of punishment for their vicious actions. These figures produce comic effects, radicalized by an elocutive technique whose performative force is purely formal. On the one hand they save a vicious one, because they lack the capacity to prove the crime. On the other hand, while fantastic, they would never be qualified for the work of converting the moral voids reported into a world endowed with sense and rationality. Here is the jocular and at the same time dramatic effect produced by the text, from a writing that points to an upside down education in a universe dominated by moral contradictions, far from eighteenth-century optimism, in which "there was a growing sense that one owed to society was civility, which began with soul searching and continued with education" (Schneider, 2015, p. 6).

Besides that, these figures of rhetoric are the basis of the artful procedure of this narrative and potentiate the comic and extraordinary effects of the text, as in the description of the election of the candidates Caneca and Nebraska, who wage in a legal dispute that will be effected by the criteria of the faculty of testimonial and interpretative proof of the texts. "The ball drawn from the bag was Nebraska's. There was, however, a mistake", for missing the last letter (Assis, 2018, p. 442). Yet, five witnesses defended the victory of Nebraska, while Caneca requested to prove his triumph by the arguments of a great philologist, who was, moreover, a good metaphysician and not a vulgar mathematician.

"First of all," he said, "you should note that the absence of the last letter of the name 'Nebraska' is no accident. Why was it left incomplete? Not through fatigue or love of brevity, since only the final letter, a mere $a$, is missing. Lack of space? Not that, either; look closely and you will see that there is still space for another two or three syllables. Hence the omission is intentional, and the intention could only be to draw the reader's eye to the letter $k$, being the last one written, hanging there abandoned and alone, devoid of purpose. Now, then, the brain has a tendency, which no law can override, to reproduce letters in two ways: the graphic form $k$, and the sonic form, which could equally be written $c a$. Thus, by drawing the eyes to the final letter written, the spelling defect instantly embeds it in the brain as the first syllable: $\mathrm{Ca}$. Once so embedded, the natural impulse of the brain is then to read the whole name, and thus returns to the beginning of the word, to the initial ne of Nebrask, giving us Ca-ne. There remains the middle syllable, bras, and it is the easiest thing in the world to demonstrate how that can be reduced to another $c a$. I will not, however, demonstrate precisely how, since you lack the necessary preparation for a proper understanding of the spiritual or philosophical meaning of such a syllable, along with its origins and effects, its phases, modifications, logical and syntactical consequences, both deductive and inductive, as well as symbolic, and so forth. But taking that as read, we are faced with the final and incontrovertible proof of my initial assertion that the syllable $c a$ is indeed joined to the first two, $\mathrm{Ca}$-ne, giving us the name Caneca" (Assis, 2018, p. 442).

Unaware of the materiality of formal proof, this great philologist resorts to the word's spiritual or philosophical meaning, fomenting a complete methodological disorder whose acuity is comical, concretized by a figural procedure (Note 7). Here, the fantastic comes from impertinent reasoning that disconcerts the credible laws that constitute the universe that can be recognized by the reader. By manipulating the ingeniously the artifices of argumentation, this good metaphysician turns the impossible into something possible, the unlikely into something demonstrable. To be more precise, the acuity of the technical procedure becomes the efficient cause of reading which recognizes conventions of the genre. There is no essence of the ideal forms in the name of which the discourse devotes its adherence. The Most Serene Republic is an ironic description of a social regime ruled by characters who personify the vices of the passions, the dispositions of character.

Only perseverance, a quintessential virtue of a republic deformed by the excesses of corruption, may be able to withstand the burden of perennial waiting for a virtuous city. In the center of the deliberative council that deals with the abuses, carelessness and gaps of the election, Erasmus becomes the "Tasked with notifying the final legislative modification to the ten worthy ladies responsible for weaving the electoral bag" (Assis, 2018, p. 443). Indeed, Erasmus' narration permits the contemplation of the juxtaposition of the animal world with the human world, of the relation of Penelope's fable to the republic of spiders, of the web that made and unmade the bag of balls with Penelope's famous web, "awaiting the return of her husband Ulysses". In the process of reading that identifies the semantic similarities produced by metaphors, the metonymy gains argumentative force, transforming the vices of this Most Serene Republic into an allegory of the nineteenth-century Brazilian republic, amplified comically by the fantastic character of the presented reasonings.

\section{Conclusion}

The virtues of serenity and wisdom do not constitute the driving force of this world, since they are "the Penelopes of our republic," Erasmus said in conclusion. "Aim to be as chaste, patient, and talented as she. Weave the bag 
again, ladies, weave it again, until Ulysses, weary of wandering, comes back to take his rightful place among us. Ulysses is Wisdom" (Assis, 2018, p. 443). Remembering the Platonic formula, Penelope's fable is the copy imitated by this fiction, which in its turn is a copy of the city of Plato, in other words, fiction of a utopia that dissolves in the impossibility of achieving wisdom. Ironically, Platonic reason is weakened by the poisons applied by its main enemy: the rhetoric of fiction. Therefore, the study of the comic in Machado's texts presupposes an understanding of the conventions of the fantastic genre, which, analyzed as a unit endowed with pragmatic properties determined by the situation of enunciation, requires the unveiling of the rhetorical devices constituting their syntactic properties. Here, these devices, present in the syntax of The Most Serene Republic, are efficient cause of the comic and fantastic effects realized by the reader who reads them from the norms of the genre that narrates the wonder in order to satirize a world whose vices dominate current opinions.

\section{References}

Assis, M. (2018). The Collected Stories of Machado de Assis. Translated by Margaret Jull Costa and Robin Patterson. Foreword by Michael Wood. New York/ London. Liveright Publishing Corporation, 2018.

Auerbach, E. (1953). Mimesis: The Representation of Reality in Western Literature. Trad. Willard R. Trask (Princeton: Imprensa da Universidade de Princeton, 1953).

Barthes, R. (1987). Criticism and Truth. Translated and edited by Katrine Pilcher Keuneman (Minneapolis: University of Minnesota Press, 1987).

Booth, W. (2007). The rhetoric of fiction. 2nd ed. Chicago: University of Chicago Press, 1983. Ferrari, G.R.F. The Cambridge Companion to Plato's Republic. Edited by G.R.F. Ferrari. Cambridge University Press, 2007.

Herrmann, F. G. (2007). The Idea of the Good and the Other Forms in Plato's Republic. In: Pursuing the Good: Ethics and Metaphysics in Plato's Republic. Edinburgh University Press, 202-230 (2007).

Jackson, R. (1981). Fantasy: The Literature of Subversion. London and New York, NY: Methuen, 1981.

Marie-Rose, L. (1987). Rhetorical Analysis: Towards a Tropology of Reading. In: New Literary History, 9(3), Rhetoric I: Rhetorical Analyses (Spring, 1978), 619-625 Published by: The Johns Hopkins University Press Stable. https://doi.org/10.2307/468459.

Sandner, D. (2004). Fantastic Literature: A Critical Reader. Westport, CT: Praeger, 2004.

Schneider, A. K. (2015). Studies in the Rhetoric of Fiction. By Ana-Karina Schneider. Cambridge Scholars Publishing. Lady Stephenson Library, Newcastle upon Tyne, 2015.

Skinner, Q. (1978). The Foundations of Modern Political Thought. Vol 1: The Renaissance. Cambridge: Cambridge University Press, 1978.

Sullivan, C. W. (2001). Folklore and Fantastic Literature. In: Western Folklore, 60(4) (Autumn, 2001), 279-296 Published by: Western States Folklore Society Stable URL. https://doi.org/10.2307/1500409.

Todorov, T., \& Richard, M. (1976). The Origin of Genres. In: New Literary History, 8(1), Readers and Spectators: Some Views and Reviews (Autumn, 1976), pp. 159-170. https://doi.org/10.2307/468619

\section{Notes}

Note 1. "The word "impossible" appears in many of the leading critical definitions of fantastic literature" (Sullivan, 2001, p. 279).

Note 2. As it was conceived by Rosemary Jackson (2009, p. 1), "literary fantasies have appeared to be 'free' from many of the conventions and restraints of more realistic texts".

Note 3. "These lines acknowledge that the writing process is itself rhetorical, tropological. Hence, the text sets up its own rhetorical analysis which is, in turn, troped by the reader. The reader's rhetorical practice reappropriates rhetorical creativity" (Marie, 1978, p. 624).

Note 4. Quentin Skinner (1978, p. 139) evidences the period marked by the successful form of republican government in Venice: "Of the various centres in which republican ideas continued to be discussed and celebrated throughout the later Renaissance, the one with the most enduring commitment to the traditional values of independence and self-government was Venice. (...) Venice settled down to na uninterrupted period of freedom and security, becoming the envy of all Italy and earning her unique reputation as the Serenissima, the most serene Republic". 
Note 5. The Republic of Venice is based on "Plato's contention in the laws that the soundest and most secure form of government consist of the three 'pure' forms in combination - the result being na amalgam of monarchy, aristocracy and democracy" (Skinner, 1978, p. 140).

Note 6. In this text, "According to the philosophical semantics of the Republic, what Socrates means by this is not a city that meets certain minimal or basic standards of justice, but rather a city that is fully just, which is in every way just and in no way unjust" (Ferrari, 2007, p.234).

Note 7. Resorting to the spiritual meaning of the word, this philologist reads the event and ignores the meaning of the word, producing a reading that transcends the materiality of the sign, through a metaphysical reasoning. In these terms, the ellipse produced by the last letter in the name of Nebraska corresponds to a revealed divine will in the real and historical world. Indeed, according to Erich Auerbach (1953, p. 195), "an event taken as a figure preserves its literal and historical meaning. It remains an event, does not become a mere sign. The Church Fathers, especially Tertullian, Jerome, and Augustine, had successfully defended figural realism, that is, the maintenance of the basic historical reality of figures, against all attempts at spiritually allegorical interpretation".

\section{Copyrights}

Copyright for this article is retained by the author(s), with first publication rights granted to the journal.

This is an open-access article distributed under the terms and conditions of the Creative Commons Attribution license (http://creativecommons.org/licenses/by/4.0/). 